\title{
sciendo \\ USE OF TRANSFORMER MULTI-LEVEL INVERTERS \\ IN PARALLEL OPERATION OF MARINE GENERATING SETS WITH PMSG
}

doi:10.2478/mape-2018-0001

Date of submission of the article to the Editor: 03/2018

Date of acceptance of the article by the Editor: 07/2018

MAPE 2018, volume 1, issue 1, pp. 3-9

dr inż. Dariusz Tarnapowicz

Maritime University of Szczecin, Poland

Abstract: The increase of energy efficiency in autonomous marine generating sets improves the overall efficiency of the ship's propulsion. One of the methods to increase the efficiency of generating sets is the use of synchronous machines with permanent magnets in sets as generators (PMSG).

The use of PMSG in connected with the need to install power converters in order to maintain constant parameters of the supply voltage and the possibility of reactive power's distribution between generating sets that work in parallel.

The article presents the possibility of using transformer multi-level inverters in parallel operation of marine generating sets with PMSG. On the basis of the results of simulation tests, the theoretical assumptions for the possibilities of active and passive power adjustment in the parallel operation of generating sets were confirmed.

Keywords: generating sets with PMSG, transformer multi-level inverters, distribution of active powers, distribution of reactive powers

\section{INTRODUCTION}

The basic condition of safety on the vessel is to ensure the continuity of power supply for devices (electricity). The ship's power plant system decides about the operation of all other systems on the ship.

The ship's power plant consists of at least two basic generating sets (Polski Rejestr Statków, 2016). Most often, these are 3, 4 or more sets. A synchronous generator driven by a mediumspeed internal combustion engine is a commonly used generating set in the shipbuilding. The idea of the ship's power network system is presented in Fig. 1.

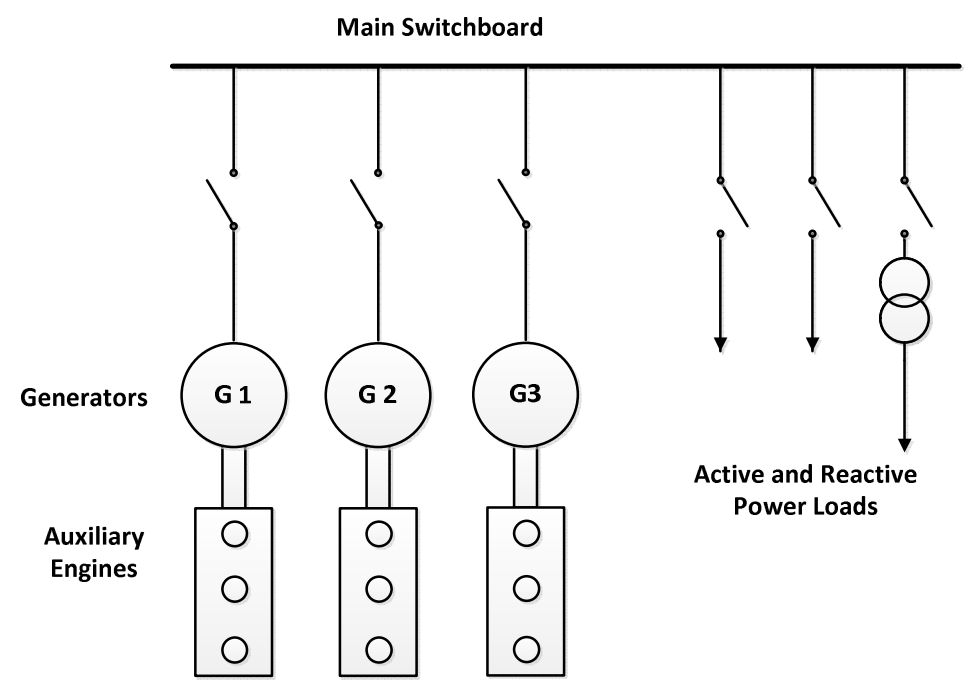

Fig. 1. A typical system of a marine power network 
Autonomous generating sets can operation independently or in parallel - depending on the power demand or the working mode of the ship. During maneuvers or in "difficult water regions", two generating sets work in parallel, although the load often does not exceed $30 \%$ (Borkowski et al., 2013; Matuszak et al., 2015; Nicewicz et al., 2014). The most important in this mode of ship's operation is the continuity of power supply, and thus the security of maneuvering.

In recent years, the need to optimize ship power plants in terms of energy has increased. This is connected with economic purposes and (above all) ecological reasons. The increase of the efficiency in generating sets contributes to the increase of the overall efficiency of the ship's propulsion.

One of the methods to increase the efficiency of generating sets is to replace the classic generators with synchronous generators with permanent magnets (PMSG).

PMSG demonstrates (within a wide load range) the highest efficiency among electrical machines. A simple compact design, brushless, no external excitation systems and no voltage regulator determine the high reliability of the generator. Low weight and inertia, as well as the ability to obtain a large number of pole pairs are properties characteristic for PMSG. These advantages determine the possibility of using PMSG in marine power plants (theswitch.com, 2018).

In addition to the listed advantages, PMSG generators have a disadvantage - i.e. the lack of voltage regulation. When changing the load, changes in the output voltage can reach up to $20 \%$ (Gawron, 2007). It is also not possible to adjust the distribution of passive power for parallel operation of generators. In order to eliminate this defect, power electronic converters are used. The autonomous Diesel-PMSG (D-PMSG) generating set, with the possibility of affecting the electrical output parameters, is presented in Fig. 2.

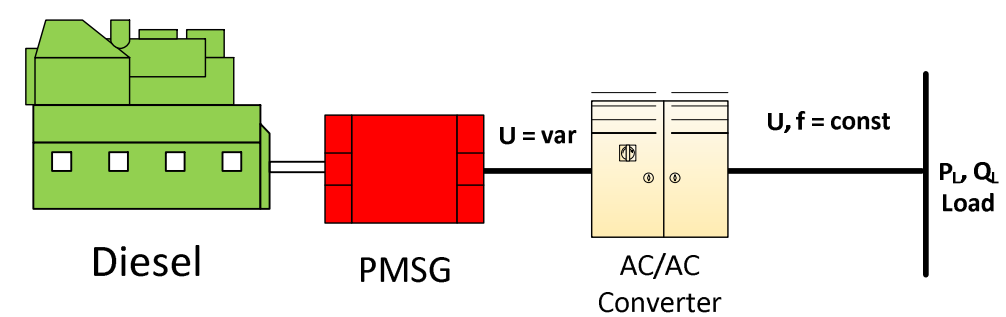

Fig. 2. Autonomous D-PMSG generating set with an AC/DC converter

The diesel engine should operate under heavy load to achieve the optimum combustion temperature. If it does not reach this temperature during maneuvers (as already mentioned), when working in parallel, the fuel will not be fully burned and it may lead to soot accumulation (literature). In the engine, the soot may cause internal glazing of cylinder bores, gluing of piston rings, reduction of compression and damage to the injectors.

One of the methods for limitation of this phenomenon is an asymmetric parallel operation of generating sets. The asymmetric operation algorithm is based on the uneven loading with active power of generating sets. One of the sets is loaded with $70-80 \%$ of the total power, and the second one at this time in $30-20 \%$. Then after the time delay (usually approx. one hour), the change of load in sets occurs (Smierzchalski, 2004). This enables to burn down the soot residue and eliminate the consequences of long-term operation of under-loaded auxiliary engines.

\section{METHODOLOGY OF RESEARCH}

Parallel operation of marine generating sets with PMSG generators

In order to enables the regulation of active and reactive power distribution in parallel operation of D-PMSG marine generating sets, the use of transformer multi-level inverters has been 
proposed (Tarnapowicz, 2010; Hartman, 2008; Al-Hitmi et al., 2018). Figure 3 shows the topology of the marine power plant's system based on this solution.

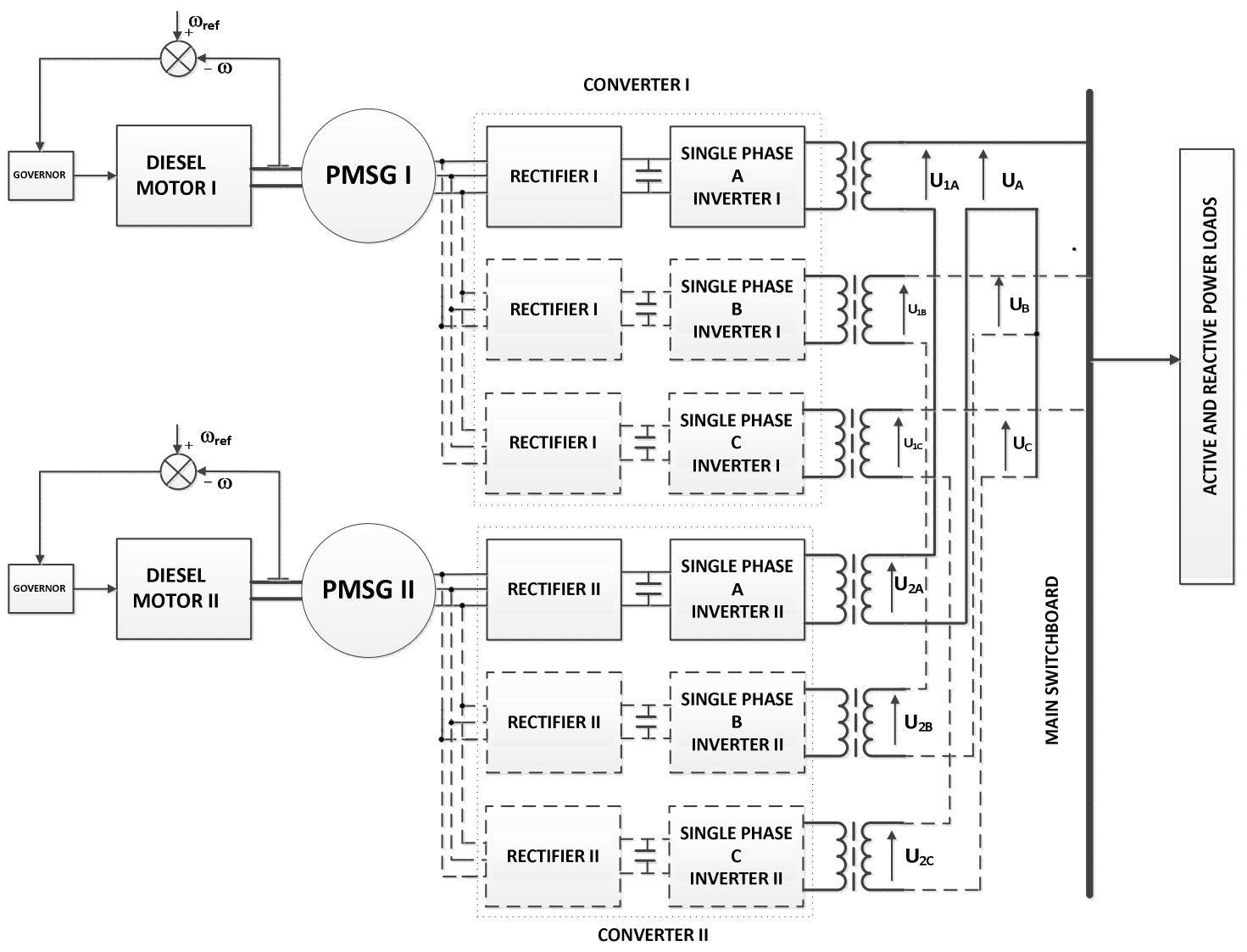

Fig. 3. Topology of the power plant system (D-PMSG) with the use of multi-level transformer inverters

The method for controlling the operation of inverters was realized on the basis of a vector analysis for one phase of the supply voltage (phase A). The control of inverters in subsequent phases (phase $B$ and $C$ ) is identical to a 120-degree shift. Figure 4.a and Figure 4.b. show diagrams for inverter's output voltages for two cases:

- The first case - symmetrical load of active and reactive power of D-PMSG sets

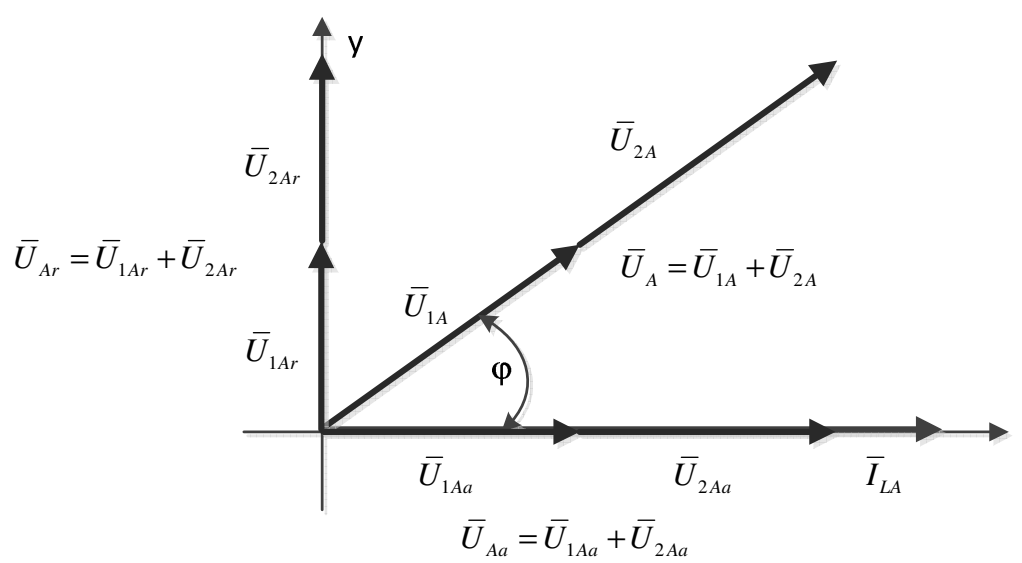

Fig. 4.a. Diagram of voltages and currents for phase A of D-PMSG (symmetrically loaded) 
- The second case - asymmetric control. Inverter I is only a source of active power $P_{1 A}=$ $80 \% P_{A}$. Reactive voltage $\bar{U}_{1 A r}=0$ (which is synonymous with the fact that the inverter l's reactive power $Q_{1 A}=0$ ). Inverter II is a source of active power $P_{2 A}=20 \% P_{A}$ (active voltage for vector module $\left|\overline{\boldsymbol{U}}_{2 A \boldsymbol{a}}\right|=20 \%\left|\overline{\boldsymbol{U}}_{1 A a}\right|$ ) and reactive $Q_{2 A}=Q_{A}$ (reactive voltage for vector module $\left.\left|\overline{\boldsymbol{U}}_{2 \boldsymbol{A} \boldsymbol{r}}\right|=\left|\overline{\boldsymbol{U}}_{\boldsymbol{A r}}\right|\right)$

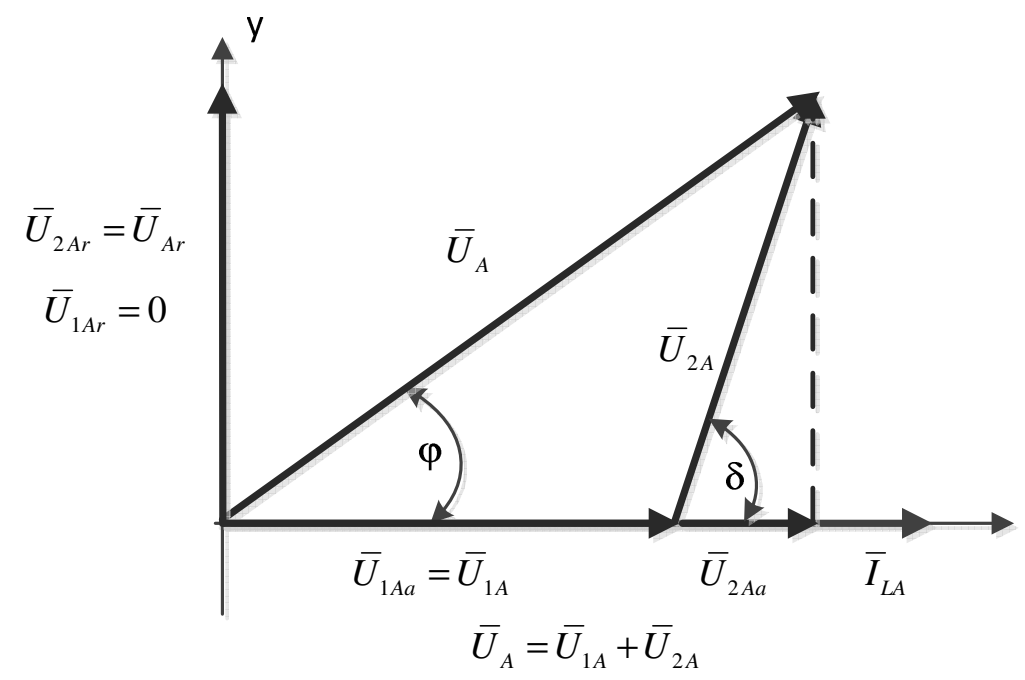

Fig. 4.b. Diagram of voltages and currents for phase A of D-PMSG generating set (asymmetrically loaded)

The set voltage for the inverter II $\left(\overline{\boldsymbol{U}}_{2 A}\right)$ results from the analysis of the voltage vector diagram (Fig. 4.b.). The phase $A$ output voltage $\bar{U}_{A}$ must be the sum of output voltages of the transformer inverters $\bar{U}_{A}=\bar{U}_{1 A}+\bar{U}_{2 A}$.

Figure 5 presents a simulation model of a multi-level transformer system, which realizes the presented strategy (implemented in the MATLAB-SIMULINK program).

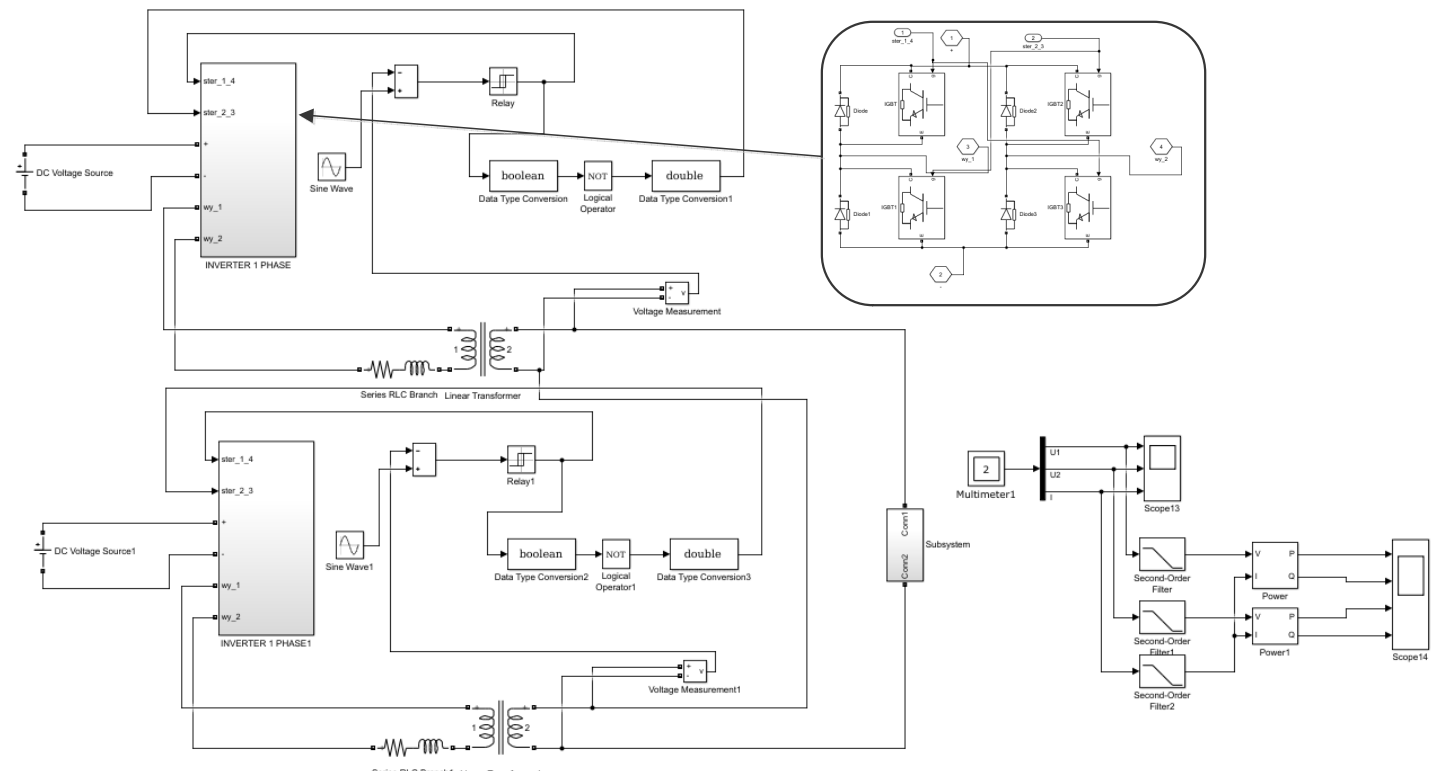

Fig. 5. Simulation model of a transformer system for multi-level inverter in phase A 
In the primary circuit of transformers, an additional inductance was included - in order to implement the hysteresis control algorithm for inverters' operation.

\section{RESULTS}

Figure 6 presents the courses of voltages and current for the first case, in which the distribution of active and reactive powers is symmetrical.

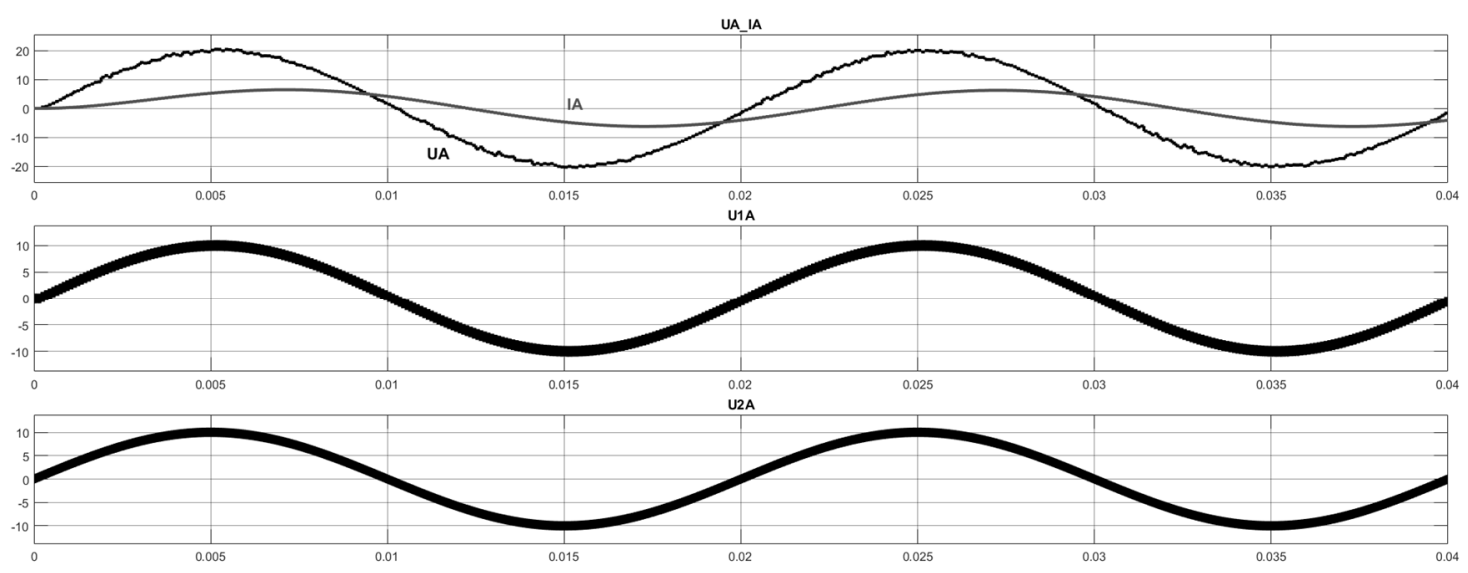

Fig. 6. UA (load voltage) and IA (load current) waveforms of phase $A$ and waveforms of output voltages for U1A and U2A transformer inverters at symmetrical load

Figure 7 shows the time courses of active powers (P1A, P2A) and reactive powers (Q1A, Q2A) at symmetrical load.
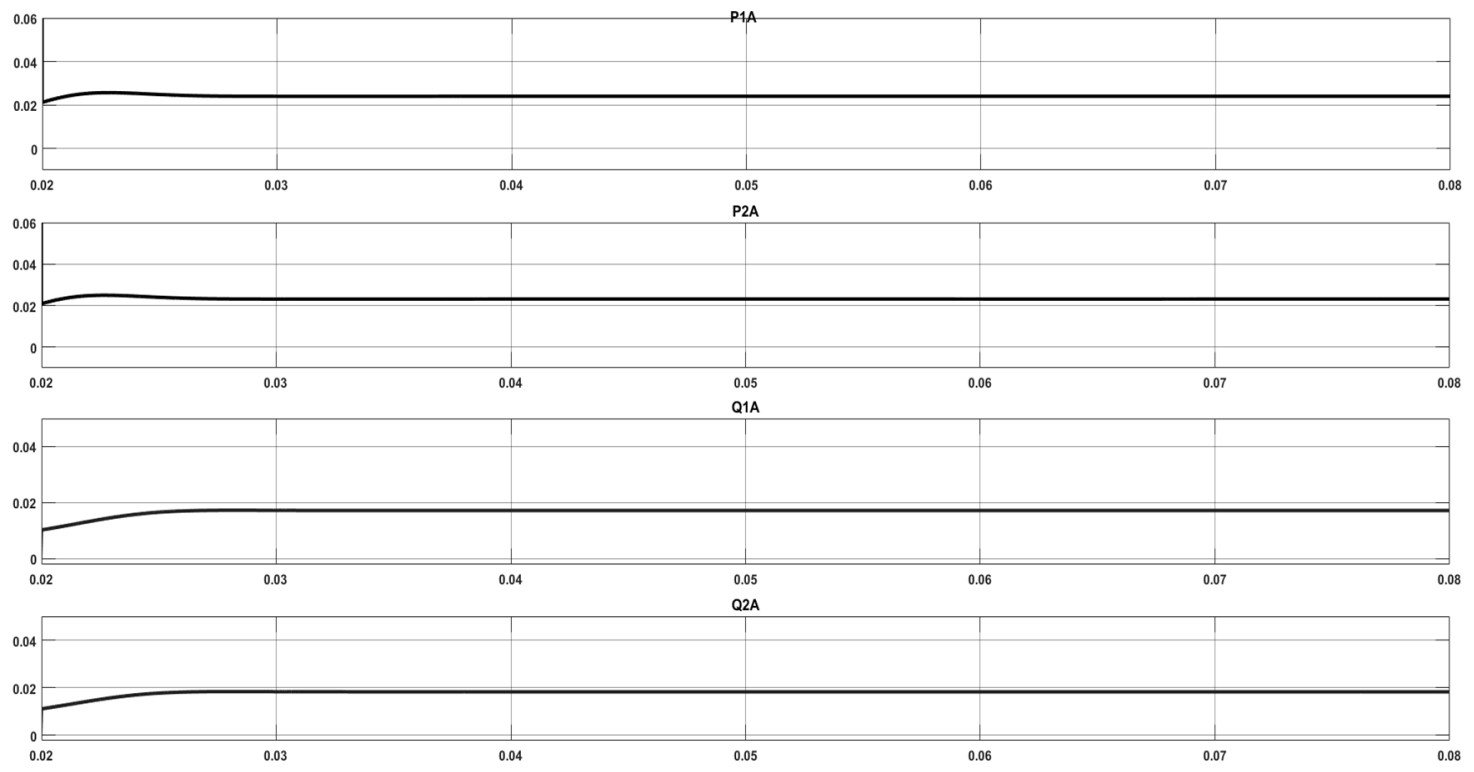

Fig. 7. Time courses of active powers (P1A, P2A) and reactive powers (Q1A, Q2A) at symmetrical load

Figure 8 presents voltage and current waveforms for the second case, in which the distribution of active and reactive power is asymmetrical. 


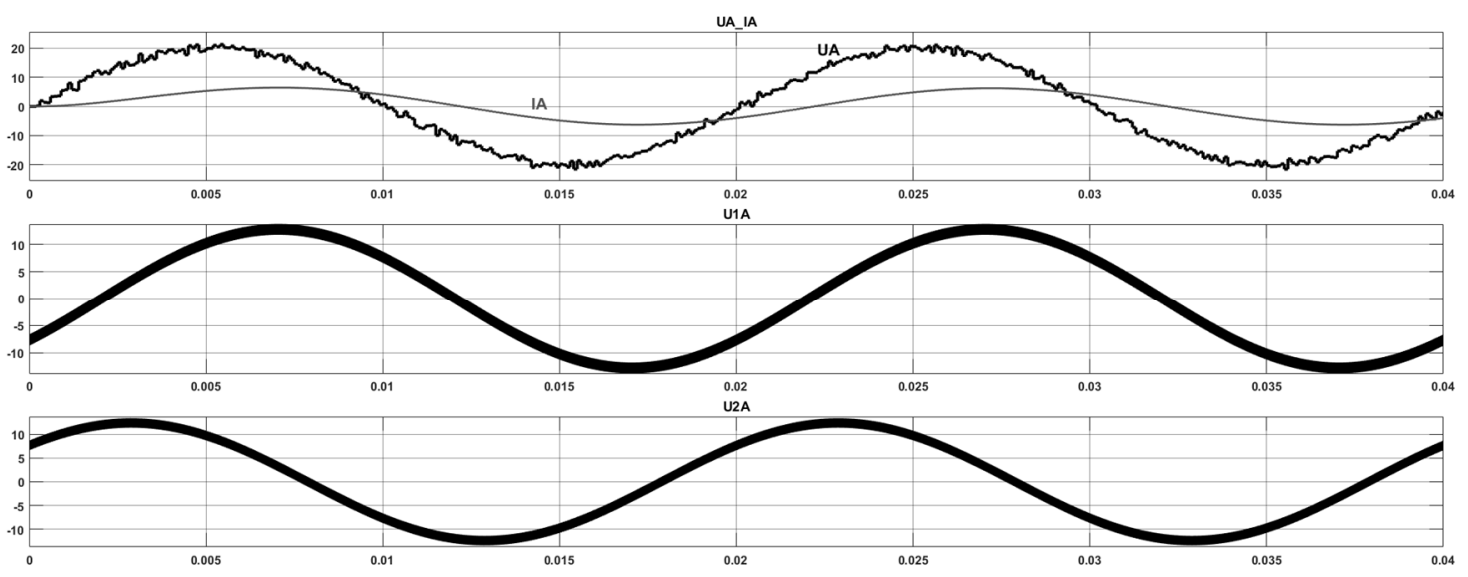

Fig. 8. UA (load voltage) and IA (load current) waveforms of phase A and waveforms of output voltages for U1A and U2A transformer inverters at asymmetrical load

Figure 9 shows the time courses of active powers (P1A, P2A) and reactive (Q1A, Q2A) with asymmetrical load. Active power $\mathrm{P} 1 \mathrm{~A}=80 \%$ of $\mathrm{PA}$ power, active power $\mathrm{P} 2 \mathrm{~A}=20 \%$ of $\mathrm{PA}$ power. The entire reactive power is supplied by the second generating set $Q 2 A=Q A$.
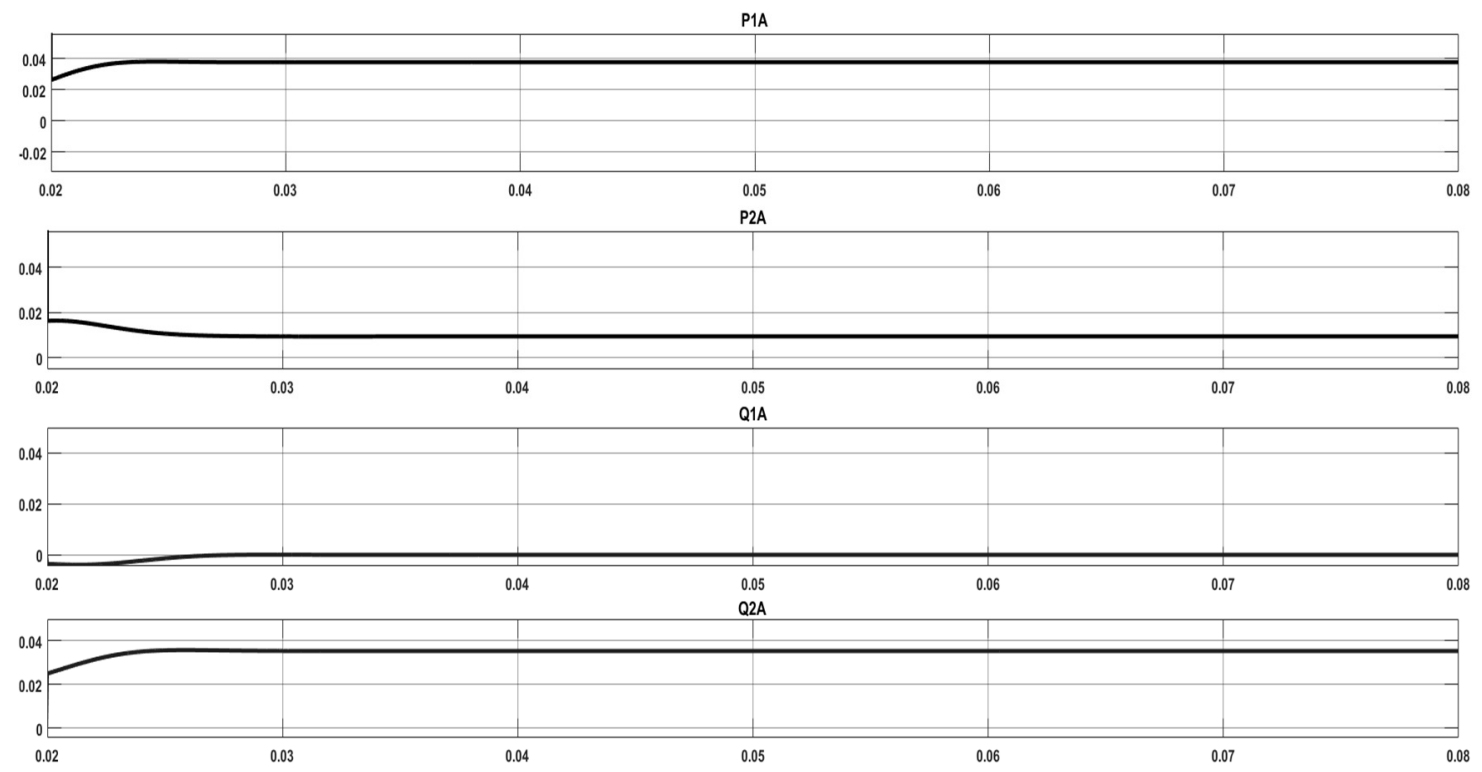

Fig. 9. Time courses for active powers (P1A, P2A) and reactive powers (Q1A, Q2A) with asymmetrical load

\section{DISCUSSION}

Multi-level transformer inverters are used to increase the voltage strength and the strength of inverter's power, as well as to improve the quality of output waveforms generated by the inverter (reduction of THD). The author has not found in the literature the use of multi-level transformer inverters for the distribution of active and reactive powers, which is proposed in this article.

\section{CONCLUSION}

The use of multi-level transformer voltage inverters enabled the regulation of active and reactive power distribution between two generating sets working in parallel. The presented concept allows for the asymmetrical operation of generating sets, and consequently, it enables 
the improvement of the operation conditions for auxiliary engines. The consequences of unfavorable long-term operation of under-loaded auxiliary engines are largely eliminated.

\section{ACKNOWLEDGEMENTS}

This research outcome has been achieved under the research project: Nowoczesne technologie w systemach "Shore to Ship" No 2/S/IEiAO/16 financed from a subsidy of the Ministry of Science and Higher Education for statutory activities.

\section{REFERENCES}

Al-Hitmi, M., Ahmad, S., Iqbal, A., Padmanaban, S. and Ashraf, I. (2018). Selective Harmonic Elimination in a Wide Modulation Range Using Modified Newton-Raphson and Pattern Generation Methods for a Multilevel Inverter. ENERGIES MDPI,11(2).

Borkowski, T., Nicewicz, G. and Tarnapowicz, D. (2013). The methodology used in defining air pollution from ships mooring in ports. SCIENTIFIC JOURNALS OF THE MARITIME UNIVERSITY OF SZCZECIN, Volume: 36 Issue: 2 Pages: 17-22 Published: 2013.

Gawron, S. (2007). Możliwości regulacji napięcia wyjściowego prądnicy synchronicznej z magnesami trwałymi. Zeszyty Problemowe - Maszyny Elektryczne 232 Nr 77/2007 Instytut Napędów i Maszyn Elektrycznych KOMEL.

Hartman, M. (2008). Selected elements of comparison analyse of multilevel voltage inverters. Przeglad Elektrotechniczny, 84(4), pp.1-3.

Matuszak, Z., Nicewicz, G., Stoklosa, J., Kaplon, A. and Jurecki, R. (2015). Results of load's observation for selected marine electric power plants systems in floating objects. Selected Problems of Electrical Engineering and Electronics WZEE. KIELCE, POLAND, SEP 17-19, 2015.

Nicewicz, G.,Sosinski, M. and Tarnapowicz, D. (2014). Identification of power factor in marine electrical grid. GEOCONFERENCE ON ENERGY AND CLEAN TECHNOLOGIES, VOL II, 14th International Multidisciplinary Scientific Geoconference (SGEM) pp 391-398, Albena, BULGARIA, JUN 17-26, 2014

Polski Rejestr Statków, (2016). Przepisy klasyfikacji i budowy statków morskich część VIII. Copyright by Polski Rejestr Statków S.A., Gdańsk.

Smierzchalski, R. (2004). Automatyzacja systemu elektroenergetycznego statku. Gdańsk 2004.

Tarnapowicz, D.(2010). The conception of the use of multi-level inverters in the shipping shaft generator systems of high power. Scientific journals of the maritime university of Szczecin. 22, pp.67-70

theswitch.com, (2018). Official Website of Yaskawa Electric Corporation. [online] Available at: //theswitch.com/download-center/data-sheets/marine/ [Accessed 20 Jan. 2018]. 